\title{
Editorial
}

\section{Farewell readers}

1

$\mathrm{s}$ the editor of this journal this was my last editorial. I now hand over the reigns to a far more energetic team and trust that they will do wonders. I have always believed that an editorial is strongest weapon that an editor has to shape the destiny of not only the journal but also the specialty. Keeping this in mind I have tried to use these pages to advise, warn, encourage, rebuke, counsel, admonish, bully, cajole, guide and inspire the younger folks towards a better future in scientific documentation.

I have always regarded the role of editor as being that of a steward, responsible for protecting and enriching the scientific assets for the good of the community, now and into the future. To be entrusted with this responsibility of editing the Indian Journal of Plastic Surgery was truly humbling, a huge learning experience and, may I say with all humility, a great honour.

If you remember I started the mission by setting a few goals for myself. These were:

1. To encourage a whole new generation of plastic surgeons to document their work.

2. To guard the frontiers of plastic surgery so that the so-called gray areas can be reclaimed.

3. To establish a harmonious balance between clinical plastic surgery and plastic surgery research.

4. To keep the specialty together and be a step ahead of sub-specialty journals.

5. To navigate the specialty towards the future by encouraging the emerging trends and yet keeping the fads far away.

6. To evaluate newer technology and see whether it

\begin{tabular}{|l|l|}
\hline \multicolumn{2}{|c|}{ Access this article online } \\
\hline Quick Response Code: & Website: \\
\hline & www.ijps.org \\
\cline { 2 - 2 } & \\
\hline
\end{tabular}

is truly beneficial or yet another attempt at clever repackaging of an old and obsolete idea.

7. To ensure ethics in practice and publication.

8. To improve our visibility on the internet and, thereby, the number of citations and impact factor.

9. To get ready for a generational change in documentation and dissemination - Mobile devices, iPods, tablets.

Whether I and my editorial board, advisors and referees succeeded is for others to judge but the satisfaction we derived from our effort was immense.

I hope to remain closely associated with this journal in days to come and be a part of its progress story. I look forward to a day when researchers and surgeons alike will credit this Journal for being instrumental in their success in terms of helping them to improve their skills and disseminate their research. I am hopeful of a day when plastic surgeons of tomorrow will tell their peers that they picked up the smartest techniques and the safest technologies from our journal.

I thank the Association of Plastic Surgeons of India for giving me this opportunity for two successive terms. I thank my editorial board, the national and international advisors and the referees for helping me all the way. Termination of my tenure can take me out of the journal but it will be an impossible task to take the journal out of me.

With best wishes for my successor Dr. Mukund Jagannathan and his team, I thank you one again and bid farewell.

\section{Surajit Bhattacharya Editor} Indian Journal of Plastic Surgery, Email: surajitbh@yahoo.co.in

How to cite this article: Bhattacharya S. Farewell readers. Indian J Plast Surg 2014;47:281. 